\title{
Graduates' perceptions of their midwifery training during the four year comprehensive nursing diploma
}

\author{
R Chetty, M Cur, School of Nursing, University of Natal \\ NS Gwele, PhD, School of Nursing, University of Natal
}

\section{Abstract}

Since its inception in 1986, the Comprehensive Nursing Diploma has received many criticisms from registered nurses, who graduated from the pre-existing programmes. This study attempts to examine the perceptions of graduates from this training programme, towards their midwifery education in terms of its adequacy in preparing them for midwifery practice. Twenty-nine graduates of the four year Comprehensive Nursing Programme completed self-administered questionnaires. Data was analysed by means of descriptive and inferential statistics, namely the paired t-test and the Wilcoxon test for matched pairs. Qualitative data was analysed to determine emerging themes and patterns. Differences in competence ratings on entry into midwifery units and those a year later, were significant at $\mathrm{p}=0.0001$.

It was found that graduates appear to have a positive perception of the midwifery component of their training programme. They found the theory aspect to be more than adequate in preparing them for their professional roles. However, with regards to clinical exposure, it was felt that the time period was too short and needed to be extended in order for them to attain clinical proficiency.

\section{Samevatting}

Sedert die instelling van die omvattende Verpleegkunde Diploma in 1986, is dit dikwels gekritiseer deur geregistreerde verpleegkundiges wat binne die voorafbestaande programme gekwalifiseer het. Hierdie studie poog om die persepsies van persone wat binne die huidige program gekwalifiseer het, te ondersoek ten opsigte van die akademiese voorbereiding vir praktisering as " $n$ verloskundige. Nege en twintig gegradueerdes van die vierjarige omvattende Verpleegkunde program het self geadministreerde vraelyste voltooi. Data is geanaliseer deur middel van beskrywende en inferensiele statistiek naamlik die gepaarde t-toets en die simmetrie toets van Wilcoxon. Kwalitatiewe data is geanaliseer om ontluikende temas en patrone to bepaal. Verskille in vaardigheidskoerse by toetrede tot verloskunde-eenhede en na een jaar later, was beduidend teen $\mathrm{p}=0.0001$. Daar is gevind dat gekwalifiseerde verpleegkundiges ' $n$ positiewe persepsie van die verloskundigekomponent van hul opleidings-program het. Hulle bevind die teorie-aspek meer as voldoende om hulle vir hul professionele rolle voor te berei. Met betrekking tot kliniese blootstelling was daar egter ' $n$ gevoel dat die tydsduur te kort is en dat dit uitgebrei behoort te word ten einde hulle in staat te stel om kliniese vaardig te word.

\section{Introduction}

The Comprehensive Nursing Diploma has been in existence for a period of almost ten years now. At ward level there have been many complaints and criticisms levelled at the graduates of this programme, from professional nurses who graduated from the pre-existing training programmes, namely the three and a half year integrated programme and the one year post-basic midwifery programme.

Since its inception a few studies have been undertaken by various members of the nursing profession to examine this training programme. Gwele and Uys (1995) carried out a study amongst nurse educators in South Africa to examine their perceptions towards the Comprehensive Basic Nursing Programme (CBNP). In their findings most respondents recognised the need for the CBNP in South Africa. Gwele and Uys (1995), cite three respondents as having made particular mention of the inadequate preparation afforded by the CBNP, in areas of midwifery and psychiatric nursing.

Nkosi (1988) examined the attitudes of black professional nurses towards the Comprehensive Nursing Diploma at
Themba Hospital in Mpumlanga. The findings revealed that a high percentage of professional nurses seemed to be negatively disposed to the Comprehensive Nursing Diploma.

\section{Background}

In 1652, when Jan van Riebeeck established a refreshment station at the Cape, midwifery services were purely domiciliary in nature (Searle 1965), with pregnant and labouring women being attended to by traditional birth attendants (Mellish 1990). Since then many changes have occurred within the nursing profession to bring about midwifery training as we know it today. For one to decide on the efficacy of a programme to produce graduates that are able to carry out their professional roles, it is imperative to evaluate the graduates' competence. 


\section{Perceptions and evaluations of competence of student nurses and graduates}

Mozingo et al. (1995) examined factors associated with perceived competency levels amongst senior baccalaureate nursing students from one particular university in America. Their most important finding that is of particular relevance to this study, was that one of the most problematic areas was related to clinical skills. Students appeared to lack confidence in their clinical competency. A large percentage of students stressed the need for more chances to practise clinical skills, while in training. As clinical exposure was increased, students perceived themselves to be more competent in the employment arena.

In another study, students also felt that clinical instructors and ward staff could improve the learning environment by being more understanding of student problems, both personal and academic (Durrheim 1993). Students also felt that lecturers need to show more confidence in them and that feedback should mostly be positive.

Kelly (1996) looked at the pressures or problems that neophyte graduates have to face when making the transition from student nurse to graduate. All subjects made mention of experiencing stress in their new roles, which appeared to be related to role anxiety. Informants also appeared not to have confidence in their competence. Due to staff shortages graduates were often not given the chance to gain experience and feel comfortable in their roles before they were expected to manage wards.

In agreement with this, Gwele and Uys (1995) found that nurse educators felt that graduates from the Comprehensive Basic Nursing Programme lacked experience. This factor lead to feelings of inadequacy and resulted in them needing more post-basic experience before they could feel confident.

\section{Perceptions of training}

Durrheim (1993) found that student nurses found the midwifery clinical learning environment to be pleasant and relaxing. One of the findings was that clinical nursing staff made more of an effort to make the labour and postnatal wards more conducive to learning, than the other areas involved in midwifery. Students also had more positive perceptions of professional nurses in the wards than of their clinical instructors. They also felt that theoretical knowledge gained in class, was relevant to clinical instruction.

However, it appeared that clinical instructors were seldom available to students in need. In keeping with this, students perceived that nursing staff made more use of clinical learning olroblems can be resolved once the student attains the relevant experience. Respondents in the Gwele and Uys (1995) study also felt that graduates need more post-basic experience before they could feel confident. Durrheim (1993) concluded that respondents view themselves to be competent to render midwifery care according to their scope of practice, as laid down by the South African Nursing Council.

Parker and Carlisle (1996) examined final year students' perceptions of their training during the Project 2000 course in the United Kingdom. Negative perceptions towards the course related to the organisation of the course. Students found the course to be fragmented and variable. Parker and Carlisle (1996), postulate that this could be related to the speed at which the course was put into effect. Due to the time constraints inadequate time was given to the preparation of the learning environment and working relationship between staff and students.

Gwele and Uys (1995) draws one's attention to a similar picture with regards to the Comprehensive Basic Nursing Programme. They state (p.9):

"A number of aspects were identified as features that would hinder the attainment of this objective. Amongst others, these were (a) fragmented clinical placements, (b) emphasis on a number of lectures and clinical hours instead of competencies, (c) a packed and rigid curriculum with 'too many nice to knows', and (d) enforced qualification in all four clinical areas."

\section{Purpose of study}

This study was conducted to specifically examine the perceptions of the four year programme graduates, regarding their midwifery education. In doing so, this study sought to attain the following objectives:

(I) Assess the views of graduates regarding the adequacy of their education, in preparing them to function as midwives.

(ii) To examine the views of the graduates regarding their competency in midwifery practice in the areas of : (a) Fundamental midwifery procedures, (b) Therapeutic \& diagnostic measures, and (c) Advanced therapeutic \& diagnostic measures.

\section{Definition of concepts}

For purposes of clearly understanding this study and to maintain consensus between reader and researcher, it is necessary to define some of the concepts that will be used.

(1) fundamental midwifery procedures: For purposes of this study, fundamental midwifery procedures, refered to midwifery procedures/skills that are essential to the practice of midwifery, without which the midwife would be unable to render care to women during pregnancy, labour and delivery, and the postnatal period.

(2) therapeutic and diagnostic measures: Therapeutic midwifery measures were seen as those interventions aimed at the resolution of maternal, foetal and neonatal complications. Diagnostic measures include the midwifery skills aimed at distinguishing and differentiating among maternal, foetal and neonatal complications, as well as the curative skills.

(3) advanced therapeutic and diagnostic measures: Refers to those measures/skills that usually fall into the scope of practice of an advanced midwife, rather than an ordinary midwife, as determined by the South African Nursing Council.

\section{Methodology \\ Design}

This was a descriptive survey, aimed at the graduates of the Comprehensive Nursing Diploma, who were presently working as midwives in midwifery departments. For purposes of this study and for accessibility, the target population was from 
Table 1: Means \& Standard Deviation of Graduates' Competencies in Midwifery Skills

\begin{tabular}{|l|l|l|l|c|}
\hline \multicolumn{2}{c}{ Initial Entry } & A Year Later \\
\hline Skills Category & Mean & SD & Mean & SD \\
\hline Fundamental Midwifery Procedures & 2.32 & 0.68 & 3.51 & 0.44 \\
\hline Therapeutic and Diagnostic Measures & 2.17 & 0.66 & 3.33 & 0.44 \\
\hline Advanced Therapeutic and Diagnostic Measures & 2.06 & 0.55 & 3.26 & 0.53 \\
\hline
\end{tabular}

the Provincial hospitals in the Durban functional region. These hospitals were as follows: (a) Addington Hospital, (b) King Edward viii Hospital and (c) R.K. Khan Hospital.

All the registered midwives, who graduated from the Comprehensive Nursing Course, who were working in one of the following units / wards: (a) labour ward, (b) antenatal ward, (c) postnatal ward and (d) antenatal clinic, were asked to participate in the study.

Based on information provided by these hospitals the number of respondents was calculated to be 44 . This was too small for sampling and as such the total population was utilised.

\section{Data collection and analysis}

The method of data collection used for this study, was the completion of questionnaires by respondents. The questionnaire listed 32 midwifery skills, which were further divided into the following categories : (a) Fundamental midwifery procedures, (b) Therapeutic/ diagnostic measures, and (c) Advanced therapeutic / diagnostic measures.

Respondents were asked to rate their perceived competence with regards to these skills: (a) when they first began working in the midwifery department and, (b) a year later, while still working in the midwifery department. A Likert type rating scale was designed by the researcher. The rating scale comprised of four categories as follows: Very competent $=4$; Competent $=3$; Fairly competent $=2$; Not competent $=1$. Respondents were also asked to express their perceptions of the education that they received in order to prepare them to practise as midwives.

In order to test for content validity of the instrument, it was administered to five registered midwives, two of whom were involved in midwifery education and the remaining three who worked in a midwifery department. They were then requested to give their input regarding whether or not, (a) they agreed with the classification of the skills into the three categories, (b) all the relevant midwifery skills had been included and (c) all the skills listed were in fact pertinent to midwifery practice.

The test-retest reliability of the instrument was tested by administering it to five members of the target population. However, only three completed questionnaires were returned. A week later the same questionnaire was administered to the same three respondents. The questionnaires, for these three respondents, from these two rounds were then compared, to check the consensus between the results. Results from these two rounds revealed an $r$ value of 0.7 , indicating the reliability of the questionnaire to elicit the necessary information. Questionnaires were then hand delivered to the different midwifery units at the three targeted hospitals. These questionnaires were then issued to all graduates of the 4 year Comprehensive Nursing programme, who were presently working in the relevant midwifery department. Completed questionnaires were collected by the researcher from the respective midwifery units. A total of 29 completed questionnaires were returned.

Quantitative data obtained by means of the Likert scale was analysed by means of descriptive and inferential statistics. Data on perceptions regarding education was analysed qualitatively. The unit of analysis was the whole statement. The information provided by placed into clusters and these clusters were The following themes and categories were identified:

$\begin{array}{ll}\text { - } & \text { adequate theory foundation } \\ \text { - } & \text { inadequate clinical experience } \\ \text { - } & \text { adequate clinical evaluation } \\ \text { - } & \text { separation of modules } \\ \text { - } & \text { age of training } \\ \text { - } & \text { large student numbers } \\ \text { - } & \text { inadequate abnormal midwifery } \\ & \text { clinical register }\end{array}$

These themes and categories are discussed later in this article.

\section{Ethical considerations}

Verbal consent was obtained from the participants by the researcher when handing out the questionnaires. Anonymity was maintained since no specific personal details were being asked of participants. Confidentiality was maintained with regards to all details of participants obtained.

\section{Findings \\ Perceptions of competence}

For all the skills listed in the questionnaire, the mean score for each skill was calculated using all 29 completed questionnaires. An average mean score was then calculated for each category.

For the category 'Fundamental Midwifery Procedures', respondents rated their initial entry competence on average as $2.32(\mathrm{SD}=0.68)$, which fell closer to 'fairly competent' on the Likert rating scale. For competence a year later, a rating of 
Table 2: Interpretation of the Likert Scale Scores

\begin{tabular}{|l|l|}
\hline Score & Interpretation \\
\hline $3.5-4$ & Very competent \\
\hline $2.5-3.4$ & Competent \\
\hline $1.5-2.4$ & Fairly competent \\
\hline $1-1.4$ & Not competent \\
\hline
\end{tabular}

3.51 ( $\mathrm{SD}=0.37$ ) was obtained, placing their perceptions between 'very competent' and 'competent'.

With regards to 'Therapeutic and Diagnostic Measures' respondents rated their initial competence as $2.17(\mathrm{SD}=0.66)$. This meant that they viewed themselves as 'fairly competent'. Competence a year later was rated as $3.33(\mathrm{SD}=0.44)$, with respondents seeing themselves as 'competent'.

For the category 'Advanced Therapeutic and Diagnostic Measures' respondents rated their initial competence as 2.06 ( $\mathrm{SD}=0.55$ ), which meant that they saw themselves, as being 'fairly competent'. The scores for competence a year later, revealed an average of $3.26(\mathrm{SD}=0.53)$, which indicated that they saw themselves as being 'competent'.

A paired $\mathbf{t}$-test was used to ascertain the statistical significance of the gather data. The paired t-test makes the assumption of normality of distribution and should normally be used for $n$ 30. In order to check the results obtained by the paired t-test the Wilcoxon test for matched pairs was conducted. This test was utilised since paired data was being analysed, rather than independent data. The Wilcoxon test for matched pairs, unlike the paired t-test, does not make the assumption of normality of distribution (Polit and Hungler, 1983). For all three categories of skills, the Wilcoxon test for matched pairs and the paired $t$-test were significant at $p=0.0001$. Hence in all categories, perceptions of competence were found to improve over time.

\section{Perceptions of educational preparation}

By means of open-ended questions respondents were asked to comment on their midwifery training during the four year Comprehensive Nursing Diploma programme. Patterns emerging from comments were either positive or negative. Themes that came to light from the positive comments were as follows.

Adequate theory component. A total of 10 (34\%) respondents made mention of finding the theory component to be adequate, citing it as intense but comprehensive. Graduates felt that as a result they were able to correlate theory with practice, and thus function adequately in their professional roles. The following statement from one of the respondents illustrates this point:

'The theoretical and practical knowledge imparted to me, by my tutors was extensive, very informative and interesting and therefore adequately prepared me for practice as a midwife,

Contribution by ward/unit staff. Only eight (28\%) gradu- ates reported that ward staff were also responsible for making their educational preparation a success. According to one respondent, ward staff were 'knowledgeable and always willing to teach'. As graduates neared the end of their midwifery training they were given more opportunities to make decisions concerning patient care, a special mention being made of labour ward in this regard. The following statement from one of the respondents demonstrates the benefit derived from ward staff.

' The close supervision of our clinical teaching department and the registered midwives of the midwifery department, helped me tremendously.'

Other positive comments. One or two graduates commented on other positive aspects of the midwifery component. These were, (a) constant evaluation by clinical teaching staff leading to feelings of competence, (b) adequate teaching and learning opportunities and (c) separation of course into modules, which lead to information being learnt in a systematic fashion.

Negative aspects of the midwifery training were outlined as follows.

Inadequate practical experience. Eleven respondents stated that time spent in the practical field as students had been inadequate, therefore, they did not feel practically competent at the end of the course. One respondent also complained about the practical aspect being 'too rushed'. As a result more practice was needed before they could function as independent practioners. Another graduate reported that time spent in each unit in the midwifery department had been inadequate. She stated that just when 'proficiency' was attained, they were moved to new areas. As a result they had to relearn procedures when they came back to work as qualified midwives in the midwifery department. One graduate felt that the South African Nursing Council's 15 delivery requirement for registration, was in fact inadequate for competence.

Exposure to abnormal midwifery. Another area that warrants looking at according to $6(21 \%)$ respondents, is that of abnormal midwifery. Respondents felt that while they were able to render care to patients with no complications, they would not have been able to render care to patients with complications and abnormal conditions, after graduation. They instead needed more exposure after qualifying to be competent in this area.

Other negative comments. One or two respondents made mention of other negative aspects of the midwifery training. These were, (a) the volume of information was too vast for the course, (b) separation of modules by one year, lead to forgetting, (c)the midwifery course being placed too early in the programme resulted in it being stressful and (d) not being able to get much 'hands on' experience in the neonatal intensive care units.

\section{Student recommendations}

Finally respondents were asked what they would change about the programme, if they were given the power to do so.

Lengthen time spent in clinical field. A total of $12(41 \%)$ respondents felt strongly that the course should allow more time in the clinical learning area. This would allow them to 
correlate theory with practice, and would give them more confidence since they would be better able to make decisions concerning patient care. Extending practical learning time would also enable students to assist with and learn about abnormal conditions and complications in midwifery.

Lengthen duration of entire course. Another 10 (34\%) respondents also mentioned extending the duration of the midwifery component, so as to have more time all around. Four respondents felt that the course should last for one year rather than 6 months. If the course was extended, respondents felt that they would feel confident to carry out their duties once qualified. They also expressed that this would also enable them to perform their teaching function more efficiently as well.

Other recommendations. One respondent said that they would decrease emphasis on the midwifery clinical requirement register and instead promote learning through 'willing, active participation'. It was also suggested that the number of clinical teaching staff be increased to cater for students clinical teaching needs. One respondent also highlighted the need for more home visiting to take place for continuity of care. Two graduates suggested combining the two modules in midwifery and not allowing for the time lapse as already mentioned. One respondent also suggested that midwifery should be done after the general nursing and psychiatric components in the four year Comprehensive programme. One graduates felt that more effort should be made to build confidence in students. It was also suggested, by one respondent, that the size of midwifery classes be decreased, so as to ensure that all students get more individual attention.

\section{Discussion}

\section{Perceptions of competence}

One of the findings of the study, was that respondents rated themselves as 'fairly competent', with regards to 'fundamental midwifery procedures', upon entry into a midwifery unit as a qualified midwife. It would appear that graduates seemed to have little confidence in their clinical competence. Inadequate confidence with regards to clinical competence upon graduation was found in graduates of the Dalhousie University School of Nursing, Nova Scotia, Canada (Barrett et al. 1996).

The respondents were also asked to rate their competence with regards to the same skills, 'a year later'. It was found that they rated their competence as significantly higher. Clinical competence was now perceived as falling between 'very competent' and 'competent'. It can be deduced that time spent in the 'working area', had a definite effect on the respondents perceptions of their competence. Barrett et al. (1996) found this phenomenon with their study in that graduates perceptions of their competence improved with more clinical exposure gained after qualification. Hence, they (Barrett et al. 1996) concluded that more clinical experience was needed whilst in training for the graduate nurse to feel competent. In South Africa nurse educators have also observed that clinical exposure after qualification helps to improve the four year Comprehensive Nursing Diploma graduate's confidence, as well as, clinical competence (Gwele and Uys 1995).

The same was asked of the respondents for the other two categories. As can be seen from the findings, perceptions of clini- cal competence, improved in both categories, with clinical experience. It becomes clear that graduates appear to have little confidence in their clinical competency following graduation. However, exposure to the clinical area as qualified midwives, seems to have helped them gain experience and allowed them to feel more confident. This is further reinforced by their perceptions of the education that they received in preparation for their roles as midwives, which will be dealt with later.

On the whole one can conclude, that the four year Comprehensive Diploma programme offers a substantial midwifery training. This can be corroborated by the respondents ratings of their competence. Thus graduates of this programme appear to feel that they are able to carry out their professional roles as midwives, as outlined by their scope of practice, by the South African Nursing Council.

\section{Perceptions of educational preparation}

A positive finding of this study, was that $72 \%$ of the population of respondents felt that the midwifery education that they had received had been adequate in preparing them for their professional roles as midwives. After all, who better to judge the programme, than a product of that programme. An idea, fully supported by Barrett et al. (1996), who suggested that graduates be used to help to evaluate the curriculums in nursing schools. From this one can deduce that the negative feelings towards the four year Comprehensive Diploma programme by graduates of other pre-existing programmes, as described by Nkosi (1988) was not supported by the results of this study, with regards to educational preparation. Thus it can be thought to stem from other factors, not including the adequacy of the course.

\section{Adequate theory foundation}

Staying with positive perceptions of the respondents, it was also found that the respondents felt that they had been given adequate theoretical knowledge during their midwifery training. According to them, this sound theory base, helped them correlate their theory learnt to the practical situation. This finding correlates with data provided by respondents, from the Dalhousie University School of Nursing (Barrett et al. 1996).

Not all respondents in the present study were happy with the theory component. It was felt that the volume was too great, with too much of emphasis on subjects such as pathology and physiology. Mozingo et al. (1995), also found that respondents in their study felt the same way, with regards to anatomy and physiology. It was suggested that more emphasis be placed on learning to render care to patients, instead. Gwele and Uys (1995) also suggested that one of the factors that may be responsible for preventing students from meeting course objectives, may in fact be the curriculum. They describe the curriculum as being, "packed and rigid" (p.9).

As already mentioned by respondents, six months are allotted to midwifery during the Comprehensive programme. During this time students are expected to learn a vast amount of theory, as well as, gain clinical experience and skills. Therefore, the author agrees with Armstrong (1993) on the idea that the teaching of basic nursing care should be undertaken in a separate nursing course. Due to the time constraint placed on the midwifery component, it becomes difficult to give time 
to the teaching of basic nursing skills that the student should have already acquired by this stage of their training.

\section{Inadequate clinical experience}

Respondents did, however, feel that their exposure to the clinical learning area had not been adequate. They felt that time spent in each midwifery unit had been too short, and as a result did not allow them to be proficient in their midwifery skills. This is due to the fact that the duration of the midwifery course within the four year Comprehensive Diploma programme, has been decreased from the one year of the post basic course to six months in the basic programme.

This complaint can also be heard from graduates of other programmes, such as the baccalaureate programme at the Dalhousie University School of Nursing (Barrett et al. 1996) and baccalaureate programmes in America (Mozingo et al. 1995). It would seem that graduates need more clinical exposure during their educational preparation, in order to feel confident about their competency after graduation. This can also be borne out by the difference in the average mean scores of respondents at 'initial entry' as compared to those ' a year later'. Indicating that clinical exposure does in fact influence perceptions of competence positively.

This correlates with findings by Gwele and Uys (1995), as well as, with findings by Barrett et al. (1996), that graduates seem to need some degree of clinical exposure after qualifying, in order to feel confident about their competence and professional roles.

\section{Contribution by ward/unit staff}

A few respondents mentioned the contribution by ward/unit staff towards their learning. These respondents felt that they learnt a lot from ward staff, even more than from clinical teaching staff. They saw the ward staff as being very knowledgeable. In total contrast to findings of Lowane (1990). Respondents also felt that more clinical teachers were needed in the practical field. Once again in contrast to Lowane (1990), no mention was made of the teaching methods of clinical teachers. Teaching by clinical teachers appears to be of good quality, but it was felt that clinical teachers needed to be more available to students.

\section{Adequate clinical evaluation}

Even though respondents felt that their clinical experience had been inadequate, they did not lack all confidence in their clinical preparation. This is due to the fact that they were extensively evaluated whilst in the clinical area of their training and education.

\section{Separation of modules}

The fact that the midwifery course is divided into modules appears to be beneficial to students in training. Respondents in this study felt that this division of normal and abnormal midwifery, helped them to learn subject content properly before moving on to learn new information. It also gave them a chance to correlate theory with practice before new information was given. Therefore division of normal and abnormal midwifery seem to assist learning, by allowing the student to move progressively from easy to difficult study material. On the down side, one of the campuses separated module I (normal midwifery) from module II (abnormal midwifery) by a period of one year. This time lapse appears to be detrimental to student learning. It allows for forgetting of information learnt and students then have to relearn information that has been forgotten. One can also see how this would lead to unnecessary stress for the students. It also hinders the learners ability to correlate normal midwifery with abnormal midwifery.

\section{Age of training}

Placement of the midwifery modules within the four year Comprehensive Nursing Diploma programme is left up to the individual institutions, resulting in the modules being separated as has already been discussed. This in turn leads to midwifery training taking place at different ages at different institutions. Two respondents who had started midwifery in their second year of training, felt that midwifery took place 'too early', which resulted in it being 'very stressful', making leaning 'difficult'. Thus it would seem that midwifery education and training should be done in third and fourth year of the programme, when the student is older, more mature and has gained adequate life experience.

\section{Large student numbers}

From rata collected it would seem that student numbers influence learning. Respondents complained that due to the large student numbers, they were not able to gain adequate clinical experience in the hospital setting. This also relates to the problem of availability of clinicians, that was discussed earlier. It would stand to reason that as student numbers increase, so to must the numbers of clinical teachers. Otherwise it becomes very difficult for students in training to get individual attention from their clinical teachers.

There appears to be two ways to solve this problem. Firstly, one can cut down on student numbers. This will allow students to get adequate clinical experience, as well as, individual attention. However, this may pose the problem of a shortage of qualified staff. The other option is to allow student numbers to remain large and instead, increase the availability of clinical placements for these students, making more use of polyclinics and other primary health care settings. This has the added benefit of varying of clinical experiences and broadening the student's knowledge base.

\section{Inadequate abnormal midwifery}

Respondents also complained that they gained adequate normal midwifery exposure, but lacked exposure to abnormal midwifery. If one follows through with the idea of increasing availability of clinical placements, then this problem would also be solved. In the primary health care setting, there is a decrease in the availability of doctors. Problems encountered have to be managed by the midwife, if possible. This will allow the student to observe and assist with the management of patients with problem or abnormal conditions.

\section{Clinical register}

One of the respondents suggested doing away with the midwifery clinical register of requirements. The respondent felt that it in fact hindered learning rather than promoted it. This can be seen to be true since students tend to adhere strictly to the requirements stipulated in their registers. Since the register is a requirement for registration as a midwife with the South African Nursing Council, it becomes the main focal 
point for students. As a result it can in effect prevent the student from opening themselves up to new and beneficial experiences that are not stipulated in the register. However, until a new method can be devised to ensure that student midwives get adequate clinical experience, the register remains one of the most effective ways of assessing students' clinical exposure.

\section{Recommendations}

The main recommendation is to lengthen the training period for midwifery. This will allow the student midwives the opportunity to gain more practical experience. Staying with practical experience, another way of increasing exposure will be to include more clinical placements, so that these placements are not overcrowded with students. This will enable all students to have access to practical exposure.

There is also a need for more clinical teachers, who can then give students more individual attention. Clinical teachers and ward staff also have to make an effort to involve students in more abnormal midwifery situations in the clinical field, as this area seems to be lacking.

It is recommended that midwifery modules run consecutively, to avoid forgetting of information learned and to allow students to correlate theory with practice.

Finally, due to the limitations of this study, that of population size, future research should extend the study to include more hospitals, in order to get a better picture of the midwifery component of the four year Comprehensive Nursing Diploma. This type of study could also be extended to examine perceptions of the entire programme and not just of midwifery.

\section{Conclusions}

Except for a lack of adequate clinical experience, the four year Comprehensive Nursing Diploma programme is affording adequate education and training to the student midwife, thus allowing the graduates to be able to fulfil their professional roles. Once adequate clinical experience during training is provided, graduates will also feel more confident upon qualifying.

\section{References}

ARMSTRONG, SJ 1993 : Perceptions of nursing students competence. Unpublished master's thesis. University of Witwatersrand: Gauteng.

BARRETT, M.C; ARKLIE, MM \& SMILLIE, C 1996 : Evaluating the graduates of the Dalhousie University School of Nursing baccalaureate programme: a quantitative/qualitative responsive model. Journal of Advanced nursing. 24, 1070-1076.

DURRHEIM, R., 1993. Student nurses' perception of the clinical midwifery experience as a learning environment. Curationis. 16(3), 1-5.

GWELE, NS \& UYS, LR 1995 : Views of leading nurse educators regarding the comprehensive basic nursing programme. Curationis. 18(2), 5-10.

KELLY, B 1996 : Hospital nursing: 'It's a battle!' A follow- up study of English graduate nurses. Journal of Advanced Nursing. 24, 1063-1069.

LOWANE, LB 1990 : Nursing students' perceptions of clinical learning experiences. Unpublished master's thesis, University of South Africa.

MELLISH, JM 1990 : A basic history of nursing .2nd ed. Durban: Butterworths.

MOZINGO, J; THOMAS, S \& BROOKS, E 1995 : Factors associated with perceived competency levels of graduating seniors in a baccalaureate nursing program. Journal of Nursing Education. 34(3), 115-122.

NKOSI, LG 1988 : A study of Black professional nurses' attitude towards the new Comprehensive Nursing Diploma. Kwa-Dlangezwa: University of Zululand.

PARKER, TJ \& CARLISLE, C 1996 : Project 2000 students' perceptions of their training. Journal of Advanced Nursing. 24, 771-778

POLIT, D \& HUNGLER, B 1983 : Nursing research, principles and methods. ( $2^{\text {nd }}$ ed.). Philadelphia: J.B. Lippincott Company

SEARLE, C 1965 : The history of the development of nursing in South Africa, 1652-1960. Pretoria: The South African Nursing Association.

SOUTH AFRICAN NURSING COUNCIL 1988 : Guidelines for course leading to registration as a nurse (general, psychiatric and community) and midwife. Pretoria: SANC.

TLAKULA, NRC \& UYS, LR 1993 : Nursing students' perception of clinical learning experiences as provided by the nursing staff in the wards. Curationis. 16(4). 28-31. 